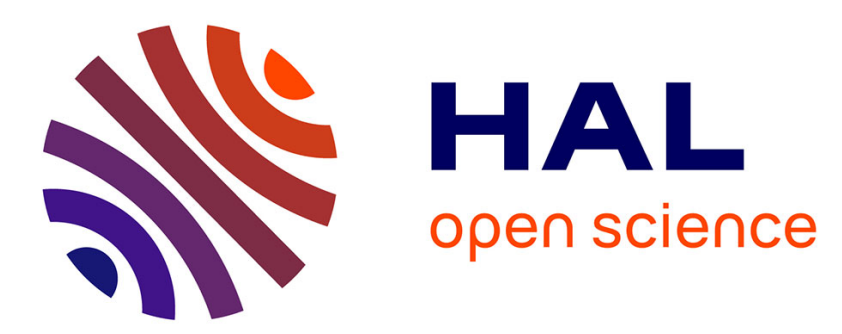

\title{
Binding of DNA to Natural Sepiolite: Applications in Biotechnology and Perspectives
}

Sandrine Ragu, Olivier Piétrement, Bernard Lopez

\section{To cite this version:}

Sandrine Ragu, Olivier Piétrement, Bernard Lopez. Binding of DNA to Natural Sepiolite: Applications in Biotechnology and Perspectives. Clays and Clay Minerals, 2021, 69, pp.633-640. 10.1007/s42860-021-00165-2 . hal-03432858

\section{HAL Id: hal-03432858 \\ https://hal.science/hal-03432858}

Submitted on 17 Nov 2021

HAL is a multi-disciplinary open access archive for the deposit and dissemination of scientific research documents, whether they are published or not. The documents may come from teaching and research institutions in France or abroad, or from public or private research centers.
L'archive ouverte pluridisciplinaire HAL, est destinée au dépôt et à la diffusion de documents scientifiques de niveau recherche, publiés ou non, émanant des établissements d'enseignement et de recherche français ou étrangers, des laboratoires publics ou privés. 


\section{Clays and Clay Minerals \\ Binding of DNA to Natural Sepiolite: Applications in Biotechnology and Perspectives --Manuscript Draft--}

Manuscript Number:

Full Title:

Article Type:

Funding Information:

Abstract:

Corresponding Author:

Corresponding Author Secondary Information:

Corresponding Author's Institution:

Corresponding Author's Secondary Institution:

First Author:

Sandrine Ragu

First Author Secondary Information:

Order of Authors:

Sandrine Ragu

Olivier Piétrement

Bernard Lopez

Order of Authors Secondary Information:

Author Comments:

Response to Reviewers:

We have addressed the editor's comments and answer to the questions

CLAY-D-21-00060R2

Binding of DNA to Natural Sepiolite: Applications in Biotechnology and Perspectives

Review

Agence Nationale de la Recherche Dr Bernard Lopez

Agence Nationale de la Recherche Dr Bernard Lopez

(16-CE18-0012-02)

Institut National Du Cancer $\quad$ Dr Bernard Lopez

Ligue Contre le Cancer $\quad$ Dr Bernard Lopez

(Equipe labelisée 2020)

Centre National de la Recherche Dr Olivier Piétrement

(MI-DynAFM-DNARep 2018_273085)

Conseil régional de Bourgogne-Franche- Dr Olivier Piétrement

(Graduate School EUR-EIPHI (17-EURE-

0002)

DNA manipulation is crucial for many biotechnological prospects and for medical applications such as gene therapy. This requires the amplification and extraction of DNA from bacteria and the transfer of these DNA molecules into cells, including bacterial and mammalian cells. The capacity of the natural magnesium silicate clay mineral sepiolite to bind to DNA makes it a potential useful tool for biotechnological/medical strategies. In addition, sepiolite is inexpensive and classified as non-toxic and non-carcinogenic. This review will first describe the physico-chemical interactions between sepiolite and DNA. Then, the leverage of sepiolite/DNA interactions for DNA extraction from bacteria, to optimize DNA transfer into bacteria and DNA transfection into mammalian cells are presented. Finally, the putative toxicity of sepiolite and its advantages and perspectives for future prospects, such as the improvement of immunotherapy are also discussed.

Bernard Lopez

Institut Cochin

FRANCE

Institut Cochin

Suggested Reviewers: 
1 Binding of DNA to Natural Sepiolite: Applications in Biotechnology and Perspectives

2 Sandrine Ragu ${ }^{\#, 1}$, Olivier Piétrement ${ }^{\#, 2}$, and ${ }^{1}$ Bernard S. Lopez ${ }^{*, 1}$

$31{ }^{1}$ Université de Paris, INSERM U1016, UMR 8104 CNRS, Institut Cochin, Equipe Labellisée

$4 \quad$ Ligue Contre le Cancer, Paris, France

$5 \quad{ }^{2}$ Laboratoire Interdisciplinaire Carnot de Bourgogne, CNRS UMR 6303, Université de

6 Bourgogne, 9 Avenue Alain Savary, 21078 Dijon Cedex, France

7 \#These authors contributed equally to this work

8 *Corresponding author: bernard.lopez@inserm.fr, Tel: +33 15373 2740, Institut Cochin, 24

9 rue du Faubourg St Jacques, 75014, Paris, France. 
DNA manipulation is crucial for many biotechnological prospects and for medical applications such as gene therapy. This requires the amplification and extraction of DNA from bacteria and the transfer of these DNA molecules into cells, including bacterial and mammalian cells. The capacity of the natural magnesium silicate clay mineral sepiolite to bind to DNA makes it a potentially useful tool for biotechnological/medical strategies. In

17 addition, sepiolite is inexpensive and classified as non-toxic and non-carcinogenic. This review will first describe the physico-chemical interactions between sepiolite and DNA. Then, the leverage of sepiolite/DNA interactions for DNA extraction from bacteria, to optimize DNA transfer into bacteria and DNA transfection into mammalian cells, are presented. Finally, the putative toxicity of sepiolite and its advantages and perspectives for future prospects, such as the improvement of immunotherapy, are also discussed. transfection in mammalian cells 


\section{INTRODUCTION}

Genome engineering is a major strategy for the development of new biological models of interest in academia and the applied sciences, such as biotechnological, biomedical, and agronomic research. Remarkably, this constitutes the basis of gene therapy aiming to correct an endogenous, mutated, defective gene and to restore normal physiological functions. DNA is the central biomolecule bearing the genetic information that is transmitted from one generation to another. Hence, methods aimed at extracting and purifying DNA and/or transferring DNA into living cells represent central issues in biotechnology and biomedical applications.

Notably, the development of vectors based on biohybrid materials for DNA transfer, which allows the avoidance of virus-based vectors, represents an appealing approach for the treatment of different genetic disorders (Choy et al., 2000; Lin et al., 2006; Shi et al., 2011; Wu et al., 2014; Choi et al., 2014). Among the different micro/nanoparticles, sepiolite represents an alluring solution.

Sepiolite is a natural magnesium silicate clay mineral with a micro-fibrous morphology. The size of sepiolite fibres varies according to geographical origin. For example, the length of sepiolite fibres from Taxus Basin deposits in Spain ranges from 0.2 to $0.8 \mu \mathrm{m}$ (CastroSmirnov et al., 2016; Piétrement et al., 2018). Interestingly, sepiolite is able to bind different kinds of biological molecules, including polysaccharides (Alcântara et al., 2014), lipids (Wicklein et al., 2010), proteins (Alcântara et al., 2012), and virus particles (Ruiz-Hitzky et al., 2012). These capacities make sepiolite a promising micro/nanovector for the non-viral transfer of biomolecules (Piétrement et al., 2018). Particularly, combining analyses from physics, chemistry, and biology, sepiolite has been shown to bind to DNA (Castro-Smirnov et 
al., 2016). These capabilities can be leveraged for biotechnology applications for future promising biomedical strategies.

This aim of this review was to discuss the potential biotechnological and biomedical uses of sepiolite, based on the physico-chemical characterisation of sepiolite/DNA interactions. Such interactions allow consideration of sepiolite as a promising substrate for DNA extraction from bacteria, for improving sepiolite-mediated bacterial transformation, and for mammalian cell DNA transfection. A further objective was to envision the putative toxicity of sepiolite versus its advantages and future perspectives.

\section{SEPIOLITE AND ITS INTERACTION WITH DNA}

\section{Sepiolite Structure.}

DNA/sepiolite interactions depend mainly on the sepiolite nanostructure and surface properties. Sepiolite belongs to a family of clays called pseudo-layered hydrated fibrous magnesium phyllosilicates. Its chemical formula is $\mathrm{Si}_{12} \mathrm{Mg}_{8} \mathrm{O}_{30}(\mathrm{OH})_{4}\left(\mathrm{H}_{2} \mathrm{O}\right)_{4}\left(\mathrm{H}_{2} \mathrm{O}\right)_{8}$ and it has a trioctahedral structure: two layers of tetrahedral silica sandwiching a central octahedral magnesium oxide-hydroxide layer (TOT family). Unlike other phyllosilicates, sepiolite, like palygorskite, exhibits a three-dimensional crystalline organization with surface channels and internal tunnels. The crystal structure of sepiolite was studied by Brauner and Preisinger (Brauner \& Preisinger, 1956) and is shown in Fig. 1. The internal channels have dimensions of close to $0.37 \times 1.06-\mathrm{nm}^{2}$.

Many active sites on the sepiolite surface consist of both silanol groups ( $\mathrm{SiOH}$ ) located at the periphery of the fibers and magnesium hydroxyl type $\left(\mathrm{Mg}-\left(\mathrm{H}_{2} \mathrm{O}\right)_{2}\right)$ groups located on either side of the channels (see Fig. 1). These sites play an essential role in DNA adsorption (CastroSmirnov et al., 2016) and allow the grafting of numerous chemical groups (García et al., 2011; Moreira et al., 2017; Undabeytia et al., 2019) and are responsible for the remarkable 
physico-chemical properties of sepiolite. Sepiolite also has a sorption capacity mainly due to the edge surfaces: the tunnels can accept molecules and retain them in a three-dimensional space, whereas the surface channels interact with the outside. Both participate in very different sorption mechanisms.

Like all clays, sepiolite has the property of retaining and exchanging cations with its environment, which is called the cation exchange capacity (CEC). However, the structure of sepiolite makes the internal faces of the channels difficult to access, and its threedimensional structure prevents swelling, unlike many of the two-dimensional phyllosilicate clays. Sorption is, therefore, limited to the capacity of binding to the faces of the edges of the sheets that emerge at the periphery of the fibres. For sepiolite, the CEC is quite low (20 to $30 \mathrm{meq} / 100 \mathrm{~g}$ of mineral) compared to other clays, but nevertheless plays an essential role in the ability of sepiolite to adsorb various biomolecules, such as polysaccharides (Darder et al., 2006), lipids (Wicklein et al., 2012), proteins (Alcântara et al., 2012), and viruses (Ruiz-Hitzky et al., 2009), giving rise to a great diversity of bio-nanocomposites. Finally, as a consequence of its structure, sepiolite has a large interaction surface that can be split into two contributions; the internal surface is close to $300 \mathrm{~m}^{2} / \mathrm{g}$, and the external surface ranges from 200 to $300 \mathrm{~m}^{2} / \mathrm{g}$ (mainly depending on the fineness of the fibres). This large surface of interaction (both internal and external) partly gives an understanding of how sepiolite can interact strongly with biomolecules.

This ability to adsorb cations has helped to develop the theory that clays could be the cradle of life on Earth, or, more specifically, of complex biochemical compounds that made life possible (Yang et al., 2013). The hypothesis is that the clay hydrogel, thanks in part to its structure organized in microcavities, plays a containment role for basic chemical elements that could have carried out the complex reactions at the origin of the formation of proteins, 
DNA, and ultimately all of the machinery involved in the functions of a living cell. The clay hydrogels could also then have confined and protected these chemical processes until the formation of the membrane surrounding the living cells.

In addition, the adsorption of DNA on mineral surfaces might favor horizontal gene transfer into living organisms, which may play a significant role in the evolution of living species. All these studies suggest a specific interaction between clays and nucleic acids.

\section{Sepiolite and DNA}

With the aim of using sepiolite as a new DNA vector, a study have thus shown that DNA could efficiently bind to sepiolite, notably highlighting the role of multivalent cations as enhancers of the DNA binding process (Castro-Smirnov et al., 2016). However, while monovalent cations reduce the adsorption of DNA molecules to mica (Pastre et al., 2003), surprisingly, these cations promote the adsorption to sepiolite fibres. While monovalent cations are less effective than multivalent cations, they unequivocally contribute to the adsorption process (see Fig. 2). Interestingly, the presence of polyvalent cations $\left(\mathrm{Mg}^{2+}, \mathrm{Ca}^{2+}\right.$, spermidine, or spermine) strongly stimulates the adsorption of DNA depending on the valence of the cation (see Fig. 2). These results suggest an adsorption mechanism mediated by an electrostatic bridge through hydrogen bonds between the DNA phosphate groups and the silanol groups located on the outer surface of the sepiolite, which is unlike the mica surface, where counterion correlations occur (Pastre et al., 2003; Pastré et al., 2006). Fourier-transform infrared (FTIR) spectroscopy analysis thus showed that, indeed, the interaction of DNA with sepiolite was mediated by only the external silanol groups, whereas the hydroxyl groups of the octahedral sheets of sepiolite play no role (Castro-Smirnov et al., 2016). 
121 If the DNA is adsorbed onto the sepiolite fibres, the question of its desorption also arises in

122 the context of a project to create a nano-cargo for cell transfection. In cellulo, the

123 mechanisms that could induce this desorption remain unknown, but the possibility of DNA

124 desorption in vitro has been tested through the desorption of DNA from the

125 bionanocomposite by incubating it with EDTA, a well-known metal ion chelating agent. By

126 using different DNA plasmids, the quality of the DNA recovered after its attachment to

127 sepiolite was examined and the different DNA isoforms (super-coiled, open circle, or linear)

128 were unmodified after their binding to sepiolite. This shows that sepiolite does not alter the

129 quality of DNA and that this method can be considered a new method of DNA purification

130 (Castro-Smirnov et al., 2016).

131 All these results confirmed the potential of sepiolite as an efficient cargo for DNA transfer

132 into cells. Moreover, the capacity of desorption suggests the possibility of using sepiolite for

133 DNA extraction.

135 DNA extraction and purification, especially of plasmids, is the basis of molecular biology.

136 Plasmids are circular DNA molecules that autonomously replicate in bacteria and are

137 essential tools in molecular biology and biotechnology, from bacteria to mammalian cells.

138 Indeed, they are used as DNA vectors/backbones in gene transfer technology. Hence, fusion

139 of an exogenous DNA (for example, a piece of a human DNA) allows replication and

140 amplification into bacteria. After this replication and amplification process, their extraction is

141 necessary for subsequent experiments.

142 Several methods of plasmid extraction are available commercially. These methods are more

143 or less expensive and time-consuming. The DNA binding capability of sepiolite, associated

144 with the possibility of DNA release, makes sepiolite a simple and inexpensive alternative 
method (Castro-Smirnov et al., 2020). Indeed, the binding of DNA onto sepiolite requires cations, notably divalent cations such as $\mathrm{Mg}^{2+}$ or $\mathrm{Ca}^{2+}$ (Castro-Smirnov et al., 2016). The chelation of cations with EDTA, therefore, enables the release of DNA from sepiolite, which is not covalently bound (Castro-Smirnov et al., 2020). The general protocol (Castro-Smirnov et al., 2020) can be summarized as follows:

a- Bacteria bearing plasmids are grown in the appropriate medium with the suitable selection of antibiotics.

b- At the mid-saturation state (as monitored by spectrophotometry), bacteria are pelleted by centrifugation and then re-suspended in specific buffers. Bacteria are lysed, and the DNA is denatured (the two complementary strands are separated) in alkaline buffers.

c- The addition of neutralizing buffer allows plasmid DNA (which are small DNA molecules) to renature (return to the bicatenary DNA structure), remaining soluble. In contrast, bacterial genomic DNA (which are long DNA molecules) cannot properly renature, and so they precipitate.

d- Centrifugation precipitates genomic DNA pellets and bacterial debris.

e- The supernatant (containing the plasmid DNA) is recovered. Sepiolite plus $\mathrm{Mg}^{2+}$ or $\mathrm{Ca}^{2+}$ is added, allowing plasmid DNA to bind to sepiolite, allowing the subsequent washing steps to eliminate contaminants.

f- Sepiolite-bearing DNA is centrifuged and washed with Tris buffer.

g- Then, EDTA is added to the sepiolite/DNA pellets, releasing the plasmid DNA from the sepiolite.

h- Plasmid DNA and sepiolite are then separated by centrifugation (sepiolite in the pellet and plasmid DNA in the supernatant). 
Steps (a) to (d) are common to almost all methods of plasmid extraction.

Importantly, the structures of plasmid DNA molecules are not altered by this procedure, as shown by electrophoresis and transmission electron microscopy analyses. Moreover, plasmid DNA can be processed by enzymes such as restriction enzymes (Castro-Smirnov et al., 2020). These facts attest to the good quality of the plasmid DNA extracted by the sepiolite-based method.

\section{IMPROVEMENT OF THE YOSHIDA EFFECT ON BACTERIAL TRANSFORMATION}

In bacteria and non-animal eukaryotic cells, the non-viral transfer of DNA is called transformation. In animal cells, it is called transfection.

Efficient transformation requires first rendering the bacteria to be competent for DNA transfer. However, the protocols to prepare competent bacteria are generally laborious and time consuming. One alternative is to purchase commercially competent bacteria, but this method is expensive. One advantage of the Yoshida effect protocol for bacterial transformation is that it does not require the use of competent bacteria.

In the Yoshida effect protocol, the solution containing the bacteria and the acicular material forms a colloidal solution. Upon spreading on solid agar medium in Petri dishes using a solid spreader, the sliding friction stimulates bacterial transformation (Yoshida et al., 2001;

Yoshida, 2007; Yoshida \& Sato, 2009). However, the Yoshida effect was first described with asbestos, thus raising health and toxicity concerns for its use. Sepiolite, which is considered non-toxic and non-carcinogenic (see below), can circumvent this health worry. Indeed, the fibrous nature of sepiolite favors bacterial transformation through a Yoshida-like effect (Yoshida, 2007; Yoshida \& Sato, 2009; Tan et al., 2010; Wilharm et al., 2010; Rodríguez-

Beltrán et al., 2012; Rodriguez-Beltran et al., 2013). 
192 The Yoshida effect does not absolutely require the pre-assembly of DNA with the fibers.

193 However, combining different capacities of sepiolite (i.e. the use of sonicated sepiolite, the

194 capacity to bind DNA and bacteria), a 100-fold improvement in transformation efficiency has

195 been observed (Castro-Smirnov et al., 2020). The general protocol can be summarized as

196 follows.

197 a- The use of sonicated sepiolite (sSep). Indeed, sepiolite spontaneously aggregates and

198 can be dissociated by sonication, increasing its spreading efficiency.

199 b- Pre-assembly of DNA and sSep, using the characteristics (incubation in the presence of

200 divalent cations) then centrifugation) described above, before adding the bacteria.

201 c- Pre-incubation of the sSep/DNA biohybrid material with bacteria (at the mid-phase of

202 growth) before spreading. Indeed, sepiolite can spontaneously bind to bacteria (Castro-

203 Smirnov et al., 2016, 2020) and it can thus be used for liquid decontamination. In

204 addition, this procedure favors bacterial transformation (Castro-Smirnov et al., 2020).

205 However, the Yoshida effect is still necessary because sepiolite-bacteria assembly alone is 206 not sufficient for efficient internalization.

207 Adapting these 3 conditions to the Yoshida effect, transformation efficiencies reached close

208 to $10^{6}$ transformants per microgram of DNA (Castro-Smirnov et al., 2020). Such

209 transformation efficiency is lower than that of the commercially available competent

210 bacteria but is largely sufficient for most molecular biology applications at a lower cost. This

211 method is also much less time-consuming than the classical protocols for preparing

212 competent bacteria.

214 Transfer of DNA into mammalian cells is an essential issue in biotechnology and biomedical

215 applications. Indeed, this constitutes the basis of strategies aimed at designing new model 
organisms for academic, biomedical, or agronomical research and gene therapy. However,

218 The Yoshida effect cannot work with mammalian cells because frictional forces kill them.

However, sepiolite can be spontaneously internalized into mammalian cells without

220

requiring friction, mainly through endocytosis and macropinocytosis pathways that involve

221

the invagination of the cell membrane around the sepiolite fibers, resulting in its

222

incorporation in the endosomes (intracellular organelles embedded into membranes) of the

223

cells (Castro-Smirnov et al., 2017). Interestingly, this process has a low effect on viability

224

(Castro-Smirnov et al., 2017; Ragu, Dardillac, et al., 2020). Given that sepiolite can bind DNA,

225 it can serve as a vector for stable DNA transfection into mammalian cells (Castro-Smirnov et

al., 2016). This application relies on the binding of DNA to sSep prior to the addition of the

227 sSep/DNA bio-hybrid material to the cell media. The uptake of the sSep/DNA bio-hybrid also

228 acts through the endocytosis pathway, and the intracellular sSep/DNA bio-hybrid is then

229 embedded in endosomes. The addition of drugs that destabilize endosome membranes,

230 such as chloroquine, results in a 2 -fold increase in the transfection efficiency (Castro-

231 Smirnov et al., 2016).

232 These methods of cell transfection are somewhat less efficient than the use of commercial

233 reagents but are much less expensive. Different strategies can be envisioned to increase the

234 efficiency of intake of the nanoparticles into the cell. These strategies might be based on the

235 structure of the cell membrane, which is constituted of a bi-layer of lipids. Moreover,

236 techniques that could favor the delivery from the endosomes, such as favoring endosome

237 collapse into the cells, are now address; this might favor DNA delivery into cells. Moreover,

238 the $\mathrm{pH}$ of the endosome is very acid, and thus might lead to hydrolysis of the DNA. Methods

239 controlling this issue are, therefore, under investigation. The injection of sepiolite in vivo 
should be precisely analyzed. Indeed, it could be injected into the blood micro-vessel and/or

241

242 accumulated in the liver. Moreover, the production of ROS (reactive oxygen species) and of inflammatory cytokines might generate unwanted inflammation and/or premature ageing. Therefore, the behavior and the fate of sepiolite, as well as the consequences of sepiolite injection (through different procedures such as in blood versus intra-peritoneal), should be addressed and analyzed in depth and in vivo in a mouse model before attempting this transfer in humans.

\section{TOXICITY OF SEPIOLITE IN HUMAN CELLS}

Because of the multiple potential uses of sepiolite, including its biomedical applications, the question of its toxicity has become an important issue. Its fibrous nature has led to concerns of asbestos-like effects. This can be supported by the fact that, like asbestos, sepiolite can generate a Yoshida effect and, in addition, generate DNA damage in bacteria (GonzálezTortuero et al., 2018). However, translating these conclusions to mammalian cells would represent an over-interpretation. Indeed, bacteria are much smaller than mammalian cells (approximately 1000 -fold). Therefore, while the length of a sepiolite fibre is similar to that of a bacterial cell, the sepiolite fiber is much smaller than that of a human cell (Castro-Smirnov et al., 2017; Ragu, Dardillac, et al., 2020). In addition, the genome of eukaryotes (including human cells) is embedded into a nuclear compartment, while in prokaryotes (bacteria) no nucleus exists, and DNA is contained directly in the cytoplasm. Therefore, a sepiolite fiber that penetrates bacteria can directly interact with its genomic DNA to alter it. In contrast, in mammalian cells, the sepiolite fibre that enters the cell will be in the cytoplasm and not in the nucleus. Hence, the sepiolite is not in contact with the genomic DNA (Castro-Smirnov et al., 2017; Ragu, Dardillac, et al., 2020). For DNA interaction, the sepiolite fiber should be transported into the nucleus, which appears to be an infrequent process (Castro-Smirnov et 
al., 2017; Ragu, Dardillac, et al., 2020). In agreement with this observation, the interaction of human cells with sepiolite does not trigger the DNA damage response (Ragu, Dardillac, et al., 2020), supporting the fact that sepiolite does not attack genomic DNA in mammalian cells.

Coherently, sepiolite appears to be weakly toxic in cultured mammalian cells (Castro-

Smirnov et al., 2017; Ragu, Dardillac, et al., 2020), especially at the doses used for DNA transfection, which are much lower than other classical transfection methods.

Sepiolite also induces the production of reactive oxygen species (ROS) in cells (Ragu, Dardillac, et al., 2020). Because ROS can potentially alter any biological component, including DNA, and lead to mutagenesis, this has raised some concerns about the potential toxicity of sepiolite. The respiratory chains that synthetize ATP and provide the energy required for various metabolic pathways generate ROS as by-products. However, cells can also control the production of ROS that act as secondary messengers in physiological processes (Ameziane-El-Hassani et al., 2016). In this situation, ROS are beneficial to the organism. Notably, while antioxidants have been proposed to protect against tumorigenesis, in contrast, treatment with antioxidants favors the development of lung carcinomas and metastasis (Breau et al., 2019; Le Gal et al., 2015; Wiel et al., 2019), thus underlying the potential benefit of ROS production. In addition, ROS can also trigger the induction of apoptosis, eliminating stressed cells, to the benefit of the whole organism. Hence, an intracellular increase in ROS can result from the detection of sepiolite by cells and their response but does not automatically imply that the fate of the cell or organism will be jeopardized.

Finally, ROS can oxidize lipid cell membranes, leading to lipid peroxidation (LP). However, sepiolite represses LP from the supernatants of rat brain homogenates, suggesting a putative antioxidant role for sepiolite (Cervini-Silva et al., 2015). One hypothesis is that cells respond 
to sepiolite interaction through the production of controlled ROS but, in parallel, sepiolite could also scavenge ROS, thus protecting against potential noxiousness.

One important component of the potential toxicity of fibres (such as asbestos) relies on the fact that they remain stuck in tissues, generating chronic inflammation, which can become pathogenic with time. These concerns connect two issues: the size of the fibres and the exclusion capacity of the cells to the fibres. Indeed, small fibres should more easily be excluded, thereby avoiding a potential asbestos-like effect. The large majority of the sepiolite fibres from Vallecas-Vicalvaro deposits in Spain range in length from 200 to $800 \mathrm{~nm}$ (Castro-Smirnov et al., 2016), values that are lower than those reported in the literature (Bellmann et al., 1997). Such sizes are much smaller than those of mammalian cells; therefore, the capacity of the cells themselves to exclude such sepiolite fibres thus becomes prominent for its harmlessness. Interestingly, the stable natural intrinsic fluorescence of the sepiolite used in the present study( from Vallecas-Vicalvaro deposit) enabled examination of its fate in cells (Castro-Smirnov et al., 2017; Ragu, Dardillac, et al., 2020). In particular, timelapse fluorescent video microscopy analysis revealed the spontaneous exclusion of these sepiolite fibers from mammalian cells, likely through an exocytosis process that involved the membranes of endosomes (Castro-Smirnov et al., 2017). These data can account for the low cellular toxicity of sepiolite (Denizeau et al., 1985; Castro-Smirnov et al., 2016; Ragu, Dardillac, et al., 2020). More generally, and in agreement with the size effect hypothesis, both epidemiological studies and in vitro and in vivo analyses have led to the conclusion that sepiolite, especially with fiber lengths less than $5 \mu \mathrm{m}$, does not present a health risk (Maisanaba et al., 2015). Moreover, previous biological and epidemiological analyses have led the International Agency for Research on Cancer (IARC) to classify sepiolite as non- 
311

hazardous and non-carcinogenic (McConnochie et al., 1993; Santarén \& Alvarez, 1994;

Wagner et al., 1987).

\section{PERSPECTIVES FOR IMPROVEMENT OF IMMUNOTHERAPY}

Additional bio-medical applications can be derived from the interaction of sepiolite with cells, such as immunotherapy. This strategy takes advantage of the capacity of the immune system to eliminate stressed cells. It has been applied to cancer therapy (Esfahani et al., 2020) and was recognized by the Nobel Academy (Nobel prize of Physiology or Medicine to James Allison and Tasuku Honjo, in 2018). This process is triggered by the production and excretion of inflammatory cytokines that modify the microenvironment of the cell. This leads to activation of the innate immune response, which recruits immune system cells (for instance, natural killer cells, macrophages, and lymphocytes). Tumors are classified as hot or cold, depending on whether they respond to immunotherapy. Unfortunately, the majority of tumors are cold. Therefore, strategies that are able to change the status of cold tumors to hot tumors should represent important progress in immunotherapy (Duan et al., 2020). Sepiolite is internalized into cells and recognized, leading to the production of inflammatory cytokines (Ragu, Dardillac, et al., 2020). Hence, this particularity opens a hopeful perspective to turn cold tumors into hot tumors for immunotherapy.

Additionally, grafting DNA onto sepiolite can be expected to optimize the inflammatory response. Indeed, cytoplasmic DNA is recognized by cells that induce inflammatory cytokines (Ragu, Matos-Rodrigues, et al., 2020). Thus, one hope would be that the bio-hybrid sepiolite/DNA material that delivers DNA into the cytoplasm of the cell might synergize the efficiency of cytokine production and thus the immune response.

\section{CONCLUSIONS}


DNA is negatively charged, and the first obstacle is the cell membrane, which is made of lipid bilayers that have charges incompatible with the spontaneous DNA uptake by cells. Nonviral methods use physical and chemical strategies to bypass the membrane barrier but are generally toxic to the cell. One limitation of both viral and physicochemical methods is the fact that they can transfer DNA only. One ideal strategy would be based on transport systems that can co-convey different kinds of molecules. The development of novel nanocarriers using biohybrid materials for non-viral gene transfer constitutes thus a promising approach. In this context, sepiolite is an enticing candidate as a nanocarrier for the non-viral vectorization of DNA, because it is biocompatible and is spontaneously internalized and excreted by mammalian cells. Moreover, thanks to its spontaneous fluorescence, sepiolite can be detected in cells (and maybe hopefully in animals) without requirement of fluorescent chemical grafting and can be followed in cells. Importantly, sepiolite is weakly toxic to mammalian cells and is classified as non-hazardous and noncarcinogenic by the IARC (WHO). Strategies based on natural internalization/externalization capacities of the mammalian cells are preferable to limit cell toxicity. These strategies implied that DNA should first bind to sepiolite to form a sepiolite/DNA (Sep/DNA) biohybrid. Indeed, sepiolite can adsorb different molecules very efficiently, thus allowing the development of many elaborate strategies, and, as a natural clay, sepiolite represents an answer to societal concerns regarding challenging nanotechnologies.

\section{ACKNOWLEDGMENTS}

We thank Prof. Eduardo Ruiz-Hiztky and Dr. Pilar Aranda for sharing their expertise, particularly on sepiolite, and for stimulating discussions. OP acknowledges Dr. Eric Le Cam for access to the electron microscope and helpful discussions. 
To be used for non-life science articles

359 Funding: SR and BSL were supported by grants from the Ligue Nationale contre le cancer

360 "Equipe labellisée”, ANR (Agence Nationale de la Recherche, ANR-16-CE12-0011-02, and

361 ANR-16-CE18-0012-02), and INCa (Institut National du Cancer, PLBIO18-232).

OP was supported by support from the CNRS Mission pour l'Interdisciplinarité (MI-DynAFMEURE-0002).

Conflicts of interest/Competing interests: The authors declare having no conflict of interest.

366 Availability of data and material: not applicable

367 Code availability: not applicable

368 Authors' contributions: SR, OP, and BSL wrote and corrected the manuscript.

369 To be used for articles with biological applications

370 Funding: SR and BSL were supported by grants from the Ligue Nationale contre le cancer

371 "Equipe labellisée", ANR (Agence Nationale de la Recherche, ANR-16-CE12-0011-02, and

372 ANR-16-CE18-0012-02), and INCa (Institut National du Cancer, PLBIO18-232).

373 OP was supported by the CNRS Mission pour l'Interdisciplinarité (MI-DynAFM-DNARep

374 2018_273085) and the Bourgogne Franche-Comté Graduate School EUR-EIPHI (17-EURE-

375 0002).

376 Conflicts of interest/Competing interests: The authors declare having no conflict of interest.

377 Ethics approval: Not applicable

378 Consent to participate: Not applicable

379 Consent for publication: Not applicable

380 Availability of data and material: Not applicable 
Clays \& Clay Minerals

381 Code availability: Not applicable

382 Authors' contributions: SR, OP and BSL wrote and corrected the manuscript. 


\section{REFERENCES}

384

Alcântara, A. C. S., Darder, M., Aranda, P., \& Ruiz-Hitzky, E. (2012). Zein-Fibrous Clays Biohybrid Materials. European Journal of Inorganic Chemistry, 2012(32), 5216-5224. https://doi.org/10.1002/ejic.201200582

Alcântara, A. C. S., Darder, M., Aranda, P., \& Ruiz-Hitzky, E. (2014). Polysaccharide-fibrous clay bionanocomposites. Applied Clay Science, 96, 2-8. http://www.sciencedirect.com/science/article/pii/S016913171400060X

Ameziane-El-Hassani, R., Schlumberger, M., \& Dupuy, C. (2016). NADPH oxidases: new actors in thyroid cancer? Nature Reviews. Endocrinology, 12(8), 485-494. https://doi.org/10.1038/nrendo.2016.64

Bellmann, B., Muhle, H., \& Ernst, H. (1997). Investigations on health-related properties of two sepiolite samples. Environ Health Perspect, 105 Suppl, 1049-1052. http://www.ncbi.nlm.nih.gov/entrez/query.fcgi?cmd=Retrieve\&db=PubMed\&dopt=Cita tion\&list_uids $=9400699$

Brauner, K., \& Preisinger, A. (1956). Struktur und Entstehung des Sepioliths. Tschermaks Mineralogische Und Petrographische Mitteilungen, 6(1-2), 120-140. https://doi.org/10.1007/BF01128033

Breau, M., Houssaini, A., Lipskaia, L., Abid, S., Born, E., Marcos, E., Czibik, G., Attwe, A., Beaulieu, D., Palazzo, A., Flaman, J.-M., Bourachot, B., Collin, G., Tran Van Nhieu, J., Bernard, D., Mechta-Grigoriou, F., \& Adnot, S. (2019). The antioxidant N-acetylcysteine protects from lung emphysema but induces lung adenocarcinoma in mice. JCI Insight, 4(19), e127647. https://doi.org/10.1172/jci.insight.127647

Castro-Smirnov, F. A., Ayache, J., Bertrand, J.-R. J.-R., Dardillac, E., Le Cam, E., Piétrement, O., Aranda, P., Ruiz-Hitzky, E., \& Lopez, B. S. B. S. (2017). Cellular uptake pathways of 
Clays \& Clay Minerals

407

408

409

410

411

412

413

414

415

416

417

418

419

420

421

422

423

424

425

426

427

428

429

430

sepiolite nanofibers and DNA transfection improvement. Scientific Reports, 7(1), 5586. https://doi.org/10.1038/s41598-017-05839-3

Castro-Smirnov, F. A., Piétrement, O., Aranda, P., Bertrand, J.-R. J.-R., Ayache, J., Le Cam, E., Ruiz-Hitzky, E., \& Lopez, B. S. (2016). Physical interactions between DNA and sepiolite nanofibers, and potential application for DNA transfer into mammalian cells. Scientific Reports, 6, 36341. https://doi.org/10.1038/srep36341

Castro-Smirnov, F. A., Piétrement, O., Aranda, P., Le Cam, E., Ruiz-Hitzky, E., \& Lopez, B. S. (2020). Biotechnological applications of the sepiolite interactions with bacteria:

Bacterial transformation and DNA extraction. Applied Clay Science, 191, 105613.

https://doi.org/10.1016/j.clay.2020.105613

Cervini-Silva, J., Nieto-Camacho, A., \& Gómez-Vidales, V. (2015). Oxidative stress inhibition and oxidant activity by fibrous clays. Colloids and Surfaces B: Biointerfaces, 133, 32-35. https://doi.org/10.1016/j.colsurfb.2015.05.042

Choi, G., Kwon, O.-J., Oh, Y., Yun, C.-O., \& Choy, J.-H. (2014). Inorganic nanovehicle targets tumor in an orthotopic breast cancer model. Scientific Reports, 4, 4430. https://doi.org/10.1038/srep04430

Choy, J.-H., Kwak, S.-Y., Jeong, Y.-J., \& Park, J.-S. (2000). Inorganic Layered Double Hydroxides as Nonviral Vectors. Angewandte Chemie International Edition, 39, 4041-4045. http://onlinelibrary.wiley.com/doi/10.1002/1521-3773(20001117)39:22\%3C4041::AIDANIE4041\%3E3.0.CO;2-C/abstract

Darder, M., López-Blanco, M., Aranda, P., Aznar, A. J., Bravo, J., \& Ruiz-Hitzky, E. (2006). Microfibrous Chitosan-Sepiolite Nanocomposites. Chemistry of Materials, 18, 16021610. http://dx.doi.org/10.1021/cm0523642

Denizeau, F., Marion, M., Chevalier, G., \& Cote, M. G. (1985). Absence of genotoxic effects of 
Clays \& Clay Minerals nonasbestos mineral fibers. Cell Biology and Toxicology, 1(2), 23-32. https://doi.org/10.1007/BF00717788

Duan, Q., Zhang, H., Zheng, J., \& Zhang, L. (2020). Turning Cold into Hot: Firing up the Tumor Microenvironment. In Trends in Cancer (Vol. 6, pp. 605-618). https://doi.org/10.1016/j.trecan.2020.02.022

Dupaigne, P., Tavares, E. M., Piétrement, O., \& Le Cam, E. (2018). Recombinases and related proteins in the context of homologous recombination analyzed by molecular microscopy. Methods in Molecular Biology, 1805, 251-270. https://doi.org/10.1007/978-1-4939-8556-2_13

Esfahani, K., Roudaia, L., Buhlaiga, N., Del Rincon, S. V., Papneja, N., \& Miller, W. H. (2020). A review of cancer immunotherapy: From the past, to the present, to the future. Current Oncology. https://doi.org/10.3747/co.27.5223

García, N., Guzmán, J., Benito, E., Esteban-Cubillo, A., Aguilar, E., Santarén, J., \& Tiemblo, P. (2011). Surface Modification of Sepiolite in Aqueous Gels by Using Methoxysilanes and Its Impact on the Nanofiber Dispersion Ability. Langmuir, 27(7), 3952-3959. https://doi.org/10.1021/la104410r

González-Tortuero, E., Rodríguez-Beltrán, J., Radek, R., Blázquez, J., \& Rodríguez-Rojas, A. (2018). Clay-induced DNA breaks as a path for genetic diversity, antibiotic resistance, and asbestos carcinogenesis. Scientific Reports, 8(1), 8504. https://doi.org/10.1038/s41598-018-26958-5

Le Gal, K., Ibrahim, M. X., Wiel, C., Sayin, V. I., Akula, M. K., Karlsson, C., Dalin, M. G., Akyürek, L. M., Lindahl, P., Nilsson, J., \& Bergo, M. O. (2015). Antioxidants can increase melanoma metastasis in mice. Science Translational Medicine, 7(308), 308re8. https://doi.org/10.1126/scitranslmed.aad3740 
455 Lin, F.-H., Chen, C.-H., Cheng, W. T. K., \& Kuo, T.-F. (2006). Modified montmorillonite as

456

457

458

459

460

461

462

463

464

465

466

467

468

469

470

471

472

473

474

475

476

477

478 vector for gene delivery. Biomaterials, 27(17), 3333-3338.

https://doi.org/10.1016/j.biomaterials.2005.12.029

Maisanaba, S., Pichardo, S., Puerto, M., Gutiérrez-Praena, D., Cameán, A. M., \& Jos, A. (2015). Toxicological evaluation of clay minerals and derived nanocomposites: A review. Environmental Research, 138, 233-254. https://doi.org/10.1016/j.envres.2014.12.024

McConnochie, K., Bevan, C., Newcombe, R. G., Lyons, J. P., Skidmore, J. W., \& Wagner, J. C. (1993). A study of Spanish sepiolite workers. Thorax, 48(4), 370-374. https://doi.org/10.1136/thx.48.4.370

Moreira, M. A., Ciuffi, K. J., Rives, V., Vicente, M. A., Trujillano, R., Gil, A., Korili, S. A., \& de Faria, E. H. (2017). Effect of chemical modification of palygorskite and sepiolite by 3aminopropyltriethoxisilane on adsorption of cationic and anionic dyes. Applied Clay Science, 135, 394-404. https://doi.org/10.1016/j.clay.2016.10.022

Pastré, D., Hamon, L., Landousy, F., Sorel, I., David, M.-O. O., Zozime, A., Le Cam, E., \& Piétrement, O. (2006). Anionic polyelectrolyte adsorption on mica mediated by multivalent cations: a solution to DNA imaging by atomic force microscopy under high ionic strengths. Langmuir, 22(15), 6651-6660. https://doi.org/10.1021/la053387y

Pastre, D., Pietrement, O., Fusil, S., Landousy, F., Jeusset, J., David, M.-O., Hamon, L., Le Cam, E., \& Zozime, A. (2003). Adsorption of DNA to Mica Mediated by Divalent Counterions: A Theoretical and Experimental Study. Biophysical Journal, 85, 2507-2518. http:// DOI: $\underline{10.1016 / S 0006-3495(03) 74673-6}$

Piétrement, O., Castro-Smirnov, F. A., Le Cam, E., Aranda, P., Ruiz-Hitzky, E., \& Lopez, B. S. (2018). Sepiolite as a New Nanocarrier for DNA Transfer into Mammalian Cells: Proof of Concept, Issues and Perspectives. Chemical Record, 18(7), 849-857. 
Clays \& Clay Minerals

https://doi.org/10.1002/tcr.201700078

Ragu, S., Dardillac, E., Adame Brooks, D., Castro-Smirnov, F. A., Aranda, P., Ruiz-Hitzky, E., \& Lopez, B. S. (2020). Responses of human cells to Sepiolite interaction. Applied Clay Science, 194, 105655. https://doi.org/10.1016/j.clay.2020.105655

Ragu, S., Matos-Rodrigues, G., \& Lopez, B. S. (2020). Replication stress, DNA damage, inflammatory cytokines and innate immune response. Genes, 11,(4), 409. https://doi.org/10.3390/genes11040409

Rodríguez-Beltrán, J., Elabed, H., Gaddour, K., Blázquez, J., \& Rodríguez-Rojas, A. (2012). Simple DNA transformation in Pseudomonas based on the Yoshida effect. Journal of Microbiological Methods, 89(2), 95-98. https://doi.org/10.1016/j.mimet.2012.02.013

Rodriguez-Beltran, J., Rodriguez-Rojas, A., Yubero, E., \& Blazquez, J. (2013). The Animal Food Supplement Sepiolite Promotes a Direct Horizontal Transfer of Antibiotic Resistance Plasmids between Bacterial Species. Antimicrobial Agents and Chemotherapy, 57(6), 2651-2653. https://doi.org/10.1128/AAC.02363-12

Ruiz-Hitzky, E., Darder, M., Aranda, P., del Burgo, M. Á. M., \& del Real, G. (2009). Bionanocomposites as New Carriers for Influenza Vaccines. Advanced Materials, 21, 4167-4171. http://onlinelibrary.wiley.com/doi/10.1002/adma.200900181/abstract

Ruiz-Hitzky, E., Darder, M., Wicklein, B., Fernandes, F. M., Castro-Smirnov, F. A., Martín del Burgo, M. A., del Real, G., \& Aranda, P. (2012). Advanced biohybrid materials based on nanoclays for biomedical applications. Proceedings SPIE, 8548, 85480D-85480D - 8. https://doi.org/10.1117/12.999995

Santarén, J., \& Alvarez, A. (1994). Assessment of the health effects of mineral dusts. Ind. Miner, April, 1-12.

Shi, Y.-F., Tian, Z., Zhang, Y., Shen, H.-B., \& Jia, N.-Q. (2011). Functionalized halloysite 
Clays \& Clay Minerals

503

504

505

506

507

508

509

510

511

512

513

514

515

516

517

518

519

520

521

522

523

524

525

526 nanotube-based carrier for intracellular delivery of antisense oligonucleotides.

Nanoscale Research Letters, 6(1), 608. https://doi.org/10.1186/1556-276X-6-608

Tan, H., Fu, L., \& Seno, M. (2010). Optimization of bacterial plasmid transformation using nanomaterials based on the Yoshida effect. International Journal of Molecular Sciences, 11(12), 4961-4972. https://doi.org/10.3390/ijms11124962

Undabeytia, T., Madrid, F., Vázquez, J., \& Pérez-Martínez, J. I. (2019). Grafted Sepiolites for the Removal of Pharmaceuticals in Water Treatment. Clays and Clay Minerals, 67(2), 173-182. https://doi.org/10.1007/s42860-019-00013-4

Wagner, J. C., Griffiths, D. M., \& Munday, D. E. (1987). Experimental studies with palygorskite dusts. British Journal of Industrial Medicine, 44(11), 749-763.

Wicklein, B., Darder, M., Aranda, P., \& Ruiz-Hitzky, E. (2010). Bio-organoclays Based on Phospholipids as Immobilization Hosts for Biological Species. Langmuir, 26, 5217-5225. http://dx.doi.org/10.1021/la9036925

Wicklein, B., Martín del Burgo, M. Á., Yuste, M., Darder, M., Llavata, C. E., Aranda, P., Ortin, J., del Real, G., \& Ruiz-Hitzky, E. (2012). Lipid-Based Bio-Nanohybrids for Functional Stabilisation of Influenza Vaccines. European Journal of Inorganic Chemistry, 2012, 5186-5191. http://onlinelibrary.wiley.com/doi/10.1002/ejic.201200579/abstract

Wiel, C., Le Gal, K., Ibrahim, M. X., Jahangir, C. A., Kashif, M., Yao, H., Ziegler, D. V., Xu, X., Ghosh, T., Mondal, T., Kanduri, C., Lindahl, P., Sayin, V. I., \& Bergo, M. O. (2019). BACH1 Stabilization by Antioxidants Stimulates Lung Cancer Metastasis. Cell, 178(2), 330345.e22. https://doi.org/10.1016/j.cell.2019.06.005

Wilharm, G., Lepka, D., Faber, F., Hofmann, J., Kerrinnes, T., \& Skiebe, E. (2010). A simple and rapid method of bacterial transformation. Journal of Microbiological Methods, 80(2), 215-216. https://doi.org/10.1016/j.mimet.2009.12.002 
Wu, H., Shi, Y., Huang, C., Zhang, Y., Wu, J., Shen, H., \& Jia, N. (2014). Multifunctional nanocarrier based on clay nanotubes for efficient intracellular siRNA delivery and gene silencing. Journal of Biomaterials Applications, 28(8), 1180-1189. https://doi.org/10.1177/0885328213501215

Yang, D., Peng, S., Hartman, M. R., Gupton-Campolongo, T., Rice, E. J., Chang, A. K., Gu, Z., Lu, G. Q., \& Luo, D. (2013). Enhanced transcription and translation in clay hydrogel and implications for early life evolution. Scientific Reports, 3, 3165. https://doi.org/10.1038/srep03165

Yoshida, N., Ikeda, T., Yoshida, T., Sengoku, T., \& Ogawa, K. (2001). Chrysotile asbestos fibers mediate transformation of Escherichia coli by exogenous plasmid DNA. FEMS Microbiology Letters, 195(2), 133-137.

Yoshida, N. (2007). Discovery and Application of the Yoshida Effect: Nano-Sized Acicular Materials Enable Penetration of Bacterial Cells by Sliding Friction Force. Recent Patents on Biotechnology, 1(3), 194-201. https://doi.org/10.2174/187220807782330147

Yoshida, N, \& Sato, M. (2009). Plasmid uptake by bacteria: A comparison of methods and efficiencies. Applied Microbiology and Biotechnology, 83(5), 791-798.

https://doi.org/10.1007/s00253-009-2042-4 
Fig. 1. Sepiolite structure (adapted from (Brauner \& Preisinger, 1956)).

Fig. 2. (A) The effects of the presence of cations with various valences on DNA adsorption.

Reaction conditions: $10 \mathrm{mM}$ Tris- $\mathrm{HCl}$ pH 7.5, salmon sperm DNA and sepiolite concentrations of $615 \mathrm{ng} / \mu \mathrm{l}$ and $1 \mathrm{mg} / \mathrm{mL}$, respectively (from (Castro-Smirnov et al., 2016)). TEM images of DNA condensed with (B) spermidine and (C) the interaction with sepiolite fibers. Transmission electron microscopy (TEM) imaging: DNA molecules (5 nM) were condensed in

$55310 \mathrm{mM}$ Tris- $\mathrm{HCl} \mathrm{pH} \mathrm{8,50} \mathrm{mM} \mathrm{NaCl}$, and $1 \mathrm{mM}$ spermidine. $5 \mu \mathrm{L}$ of reaction mixture was 554 deposited onto a 600 mesh copper grid coated with a thin carbon film previously activated 555 by glow discharge in the presence of 1-aminopentane (Merck, Saint Quentin Fallavier, 556 France) (Dupaigne et al., 2018). After $1 \mathrm{~min}$, the grids were washed with aqueous 2 wt.\%

557 uranyl acetate (Merck, Saint Quentin Fallavier, France) and then dried with ashless filter 558 paper (VWR, Rosny sous bois, France). TEM observations were carried out on a Zeiss 912AB 559 transmission electron microscope in bright field mode. Electron micrographs were obtained 560 using a ProScan 1024 HSC digital camera and iTEM software (Olympus, Soft Imaging 561 Solutions, Munster, Germany). 

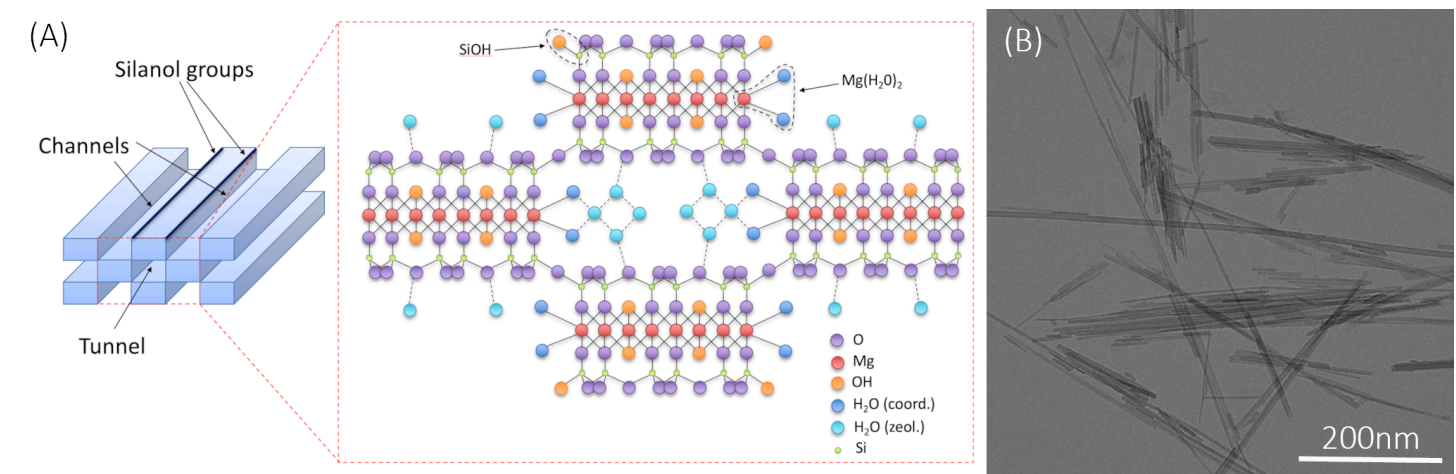
(B)

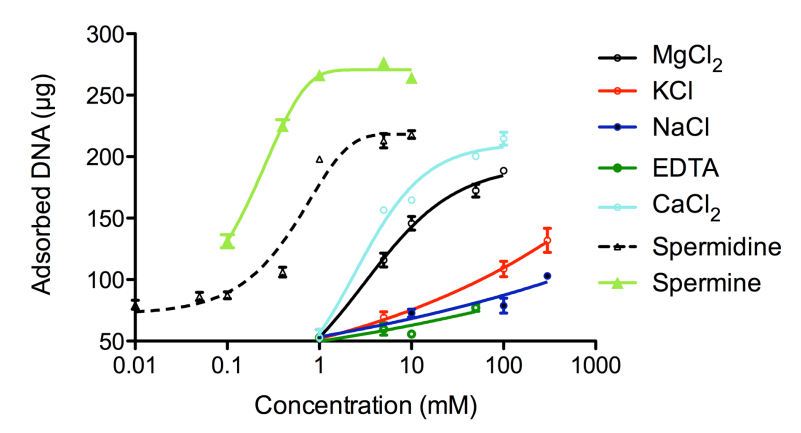

(C)

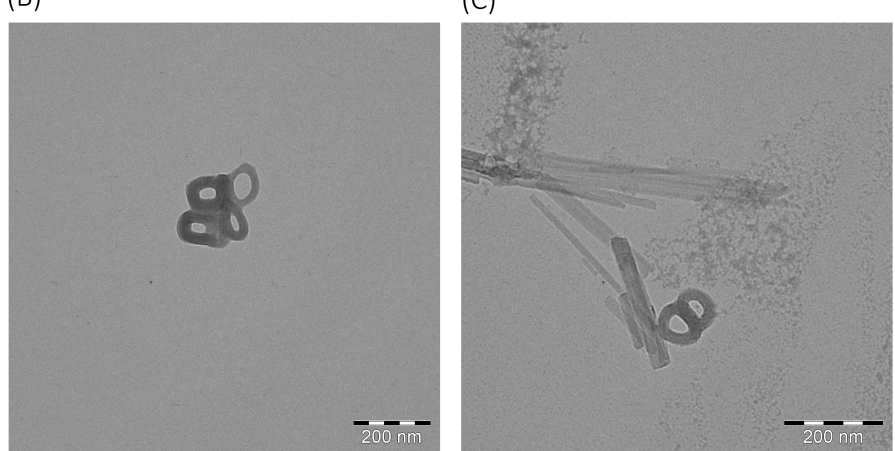


Click here to access/download Supplementary Material

21-00060 Lopez -finalwith Mark change.docx 